\title{
АНАЛІЗ БІОЛОГІЧНОЇ АКТИВНОСТІ ВОДИ ТА Ï̈ ЕНЕРГОІНФОРМАЦІЙНИХ КОПІЙ ЗА ДАНИМИ КІРЛІАНОГРАМ
}

\author{
О. П. Мінцер, В. Г. Краснобрижев ${ }^{1}$, Л. А. Пісоцька², \\ Н. В. Глухова ${ }^{3}$, Т. Д. Тепла ${ }^{4}$ \\ Національний університет охорони здоров'я України імені П. Л. Шупика \\ ${ }^{1}$ Науково-виробничий центр «Природа» \\ ${ }^{2}$ Національний технічний університет «Дніпровська політехніка» \\ ${ }^{3}$ Дніпровський державний медичний університет \\ ${ }^{4}$ ннститут геотехнічної механіки ім. М. С. Полякова НАН України
}

\begin{abstract}
Встановлено критерії біологічно активної води та її енергоінформаційних копій за даними кірліанограм, для використання в практичній біології. 3 метою дослідження та класифікації води різних типів було вирішено завдання накопичення експериментальних вибірок зображень води з різними фрізико-хімічними та біологічними властивостями, побудови бази даних зображень. На основі аналізу експериментальних даних було виявлено специфрічні ознаки, на базі яких можливо побудувати систему автоматизованої програмної класифікації. Метод кірліанфотограсрії крапель води досить інсрормативний для оцінювання природних властивостей води та може використовуватись, як експресметод.
\end{abstract}

Ключові слова: метод кірліаноротографрії, метод газорозрядного випромінювання, біологічна активність води, природна вода.

\section{ANALYSIS OF BIOLOGICAL ACTIVITY OF WATER AND ITS ENERGY INFORMATION COPIES ACCORDING TO KIRLIANOGRAM DATA}

\author{
O. P. Mintser, V. H. Krasnobryzhev ${ }^{1}$, L. A. Pisotska², \\ N. V. Hlukhova ${ }^{3}$, T. D. Tepla ${ }^{4}$ \\ Shupyk National Healthcare University of Ukraine \\ ${ }^{1}$ Research and Production Center «Nature» \\ ${ }^{2}$ Dnipro State Medical University \\ ${ }^{3}$ Dnipro University of Technology
}

${ }^{4}$ M. S. Poljakov Institute of Geotechnical Mechanics National Academy of Sciences of Ukraine

\begin{abstract}
Background. Criteria of biologically active water and its energy information copies according to kirlianograms, for use in practical biology are established.

Materials and methods. Results. In order to study and classify water of different types, it was decided to set up the accumulation of experimental samples of water images with different physicochemical and biological properties and to build a database of images. Based on the analysis of experimental data, specific features were identified, on the basis of which it is possible to build a system of automated software classification.

Conclusions. The method of Kirlian photography of water droplets is informative enough to assess the natural properties of water and can be used as an express method.
\end{abstract}

Key words: Kirlian photography method, gas discharge radiation method, biological activity of water, natural water. 


\title{
АНАЛИЗ БИОЛОГИЧЕСКОЙ АКТИВНОСТИ ВОДЫ И ЕЕ ЭНЕРГОИНФОРМАЦИОННЫХ КОПИЙ ПО ДАННЫМ КИРЛИАНОГРАММ
}

\author{
О. П. Минцер, В. Г. Краснобрыжев르, Л. А. Песоцкая², \\ Н. В. Глухова ${ }^{3}$, Т. Д.Тепла ${ }^{4}$ \\ Национальный университет здравоохранения Украины имени П. Л. Шупика \\ ${ }^{1}$ Научно-производственный центр «Природа» \\ ${ }^{2}$ Днепровский государственный медицинский университет \\ ${ }^{3}$ Национальный технический университет «Днепровская политехника» \\ ${ }^{4}$ Институт геотехнической механики им. Н.С. Полякова НАН Украины
}

\begin{abstract}
Установлены критерии биологически активной воды и ее энергоиноормационных копий по данным кирлианограмм для использования в практической биологии. С целью исследования и классификации воды различных типов была решена задача накопления экспериментальных выборок изображений воды с различными фризико-химическими и биологическими свойствами и построения базы данных изображений. На основе анализа экспериментальных данных выявлено специсрические признаки, на базе которых возможно построить систему автоматизированной программной классификации. Метод кирлианфотографии капель воды достаточно информативен для оценки природных свойств воды и может использоваться как экспресс-метод.
\end{abstract}

Ключевые слова: метод кирлианфотографрии, метод газоразрядного излучения, биологическая активность воды, природная вода.

Вступ. У зв’язку з повсюдним екологічним забрудненням водних басейнів, зниженням біологічних ресурсів, появою нових генетичних мутацій, збудників захворювань, у тому числі в рослин, актуальним $€$ розроблення системи прогнозування впливу різних зразків води на процеси життєдіяльності в біосфері з метою їх корекції.

Існуючі сучасні уявлення про структуру та властивості води засновані на неоднорідності її складових, фазових переходах, квантових ефектах. Діючим початком, що управляє інформацією, яка сприймається клітиною або клітинними органелами, є складна геометрична форма водних асоціатів. Саме така форма $€$ тією ланкою, що визначає структуру фізичних полів, властивих асоціату. Ці ж поля, в свою чергу, запускають або зупиняють внутрішньоклітинні процеси або впливають на них тим або іншим способом [1].

Вивчення подібних тонко матеріальних процесів буде зводитися до реєстрації зміни їх електрофізичних властивостей. Такою можливістю володіють методи, засновані на Ефекті Кірліан [2], а сам фізичний процес при цьому являє собою фотонну емісію об’єкта, посилену в полі високої напруги та фіксується на фотоматеріалі, Ро-плівці, дисплеї комп’ютера [3].

Мета дослідження: встановлення критеріїв біологічно активної води та її енергоінформаційних копій за даними кірліанограм, для використання в практичній біології.
Матеріал і методи дослідження. Провели кірліанографічне (Кі-фотографія) дослідження 7-и дослідних зразків води та їх інформаційних копій, приготованих на контрольних дистильованої води (КД) і на воді зі свердловини (СВД), з високим умістом заліза. Серед оригінальних вод були природні води з джерел Болгарії, у тому числі, з територій монастирів і святих місць (скельного монастиря Мадари, Дренського монастиря, монастиря Св. Петра та Павла), а також водопровідної води з Варни, Габрово, зі Святого природного джерела України (м. Приморськ).

Для отримання кірліанівського зображення зразків води використовували рентгенівську плівку, експериментальний прилад із приставкою для рідкофазних об'єктів $[4,5]$.

3 метою дослідження та класифікації води різних типів було вирішено завдання накопичення експериментальних вибірок зображень води з різними фізико-хімічними та біологічними властивостями, побудови бази даних зображень. На основі аналізу експериментальних даних у вигляді зображень газорозрядного випромінювання води виявлено специфічні ознаки, на базі застосування яких можливо побудувати систему автоматизованої програмної класифікації для віднесення зображень крапель води до відповідного типу.

При вирішенні завдання дослідження властивостей води виконано такі операції: 
1. Побудувати гістограми яскравості зображень, що дозволяють виявити геометричні та яскравісні (фотометричні) параметри зображень.

2. Виділити специфічні ознаки випромінювання для певного типу води шляхом аналізу та параметризації гістограм яскравості.

3. Усереднення специфічних ознак випромінювання для вибірок у межах одного типу води на базі розрахунку медіан та їх різниць, що з точки зору математичної статистики дозволило реалізувати стійкий (робастний) підхід до оброблення експериментальних даних, оскільки медіана $є$ експериментальним оцінюванням математичного очікування, що забезпечує стійкість до випадкових викидів і промахів.

4. Використання метрики у вигляді евклідової відстані для розв' язання завдання класифікації.

5. Побудувати алгоритм класифікації.

6. Розробити програмну реалізацію завдання класифікації.

7. Перевірка достовірності класифікації.

Для перевірки достовірності класифікації з накопиченої експериментальної бази зображень газорозрядного випромінювання виділено окрему групу тестових зображень дистильованої води. Після побудови алгоритму та програмної реалізації класифікації зображень, проведено перевірку достовірності класифікації на базі евклідової відстані шляхом перевірки результатів класифікації з вхідними даними у вигляді тестової вибірки зображень дистильованої води. В процесі перевірки класифікатора на тестовій вибірці виявлено, що 96 \% зображень класифіковано правильно.

Додатково для підтвердження відтворюваності та достовірності експериментальної реалізації методу газорозрядного випромінювання проведено дослідження з використанням тест-об'єкту. В якості тест-об'єкту використано металевий циліндр [6]. Внутрішній діаметр циліндру складав 14 мм.

Експериментальну вибірку багатократних спостережень за тест-об'єктом отримано у моноімпульсному режимі. 3 метою подальшої комп’ютерної обробки зображень виконано їх аналого-цифрове перетворення на базі застосування сканеру з роздільною здатністю 600 dpi. Розрахунки з оцінюванням метрологічних характеристик для багаторазових спостережень проводилися з субпіксельною точністю. Точність відтворення геометричних розмірів тест-об'єкту здійснювалася шляхом кількісного оцінювання діаметру (для кожного циліндру в шести різних напрямах). Математичними розрахунками перевірено статистичну однорідність та рівнорозсіюваність. Для перевірки однорідності застосовано критерій Стьюдента. При перевірці статистичної рівності дисперсії для вибірок геометричних розмірів гіпотезу щодо рівнорозсіяності підтверджено в усіх групах експериментальних даних за критерієм Фішера. Як критерій Стьюдента, так і критерій Фішера дозволили обгрунтувати та підтвердити гіпотези про статистичну однорідність і рівнорозсіюваність. У підсумку це дозволило поєднати окремі групи експериментальних спостережень в одну групу, в межах якої розраховано експериментальну оцінку математичного очікування геометричних розмірів тест-об'єкту та невизначеність вимірювань. Сумарну невизначеність вимірювань оцінено 3 урахуванням вкладу невизначеності категорії А (від впливу випадкових величин) та категорії В (обумовлена обмеженою роздільною здатністю скануючого пристрою та може бути класифікована як інструментальна складова невизначеності аналого-цифрового перетворення). Кількісне значення сумарної невизначеності внутрішнього діаметра циліндра складає 61,7 мкм.

Створено базу Ki-зображень на рентгенівській плівці для декількох типів вод. В якості типових вод (ТВ) використано такі: дистильована (1), водопровідна (в / в, 2), природна (3) і з територій монастирів (монастирська, 4). При побудові системи автоматизованої класифікації за типами води в якості основного способу для порівняння геометричних і фотометричних (тобто яскравості) характеристик зображень застосовано гістограми [7].

Кірліанограми крапель води в кількості 50 для кожного експериментального зразка сканували, зберігали в базі параметрів гістограм яскравості, програмно розраховували значення евклідової відстані для медіан висот стовпців гістограми (ЕРM, у.о.), а також різниць висот у сусідніх інтервалах із величинами типових вод (ЕРРМ, у.о.). Найменші значення евклідової відстані вказують на максимальну близькість досліджуваного зразка до одного з типових класів води. 
Інформаційні копії з оригінальних зразків води готували з використанням приладу для енергоінформаційного перенесення [8].

Біологічний експеримент полягав у розміщенні цибулин одного розміру (1-1,5 см) і виду на вологу підстилку з різною водою для пророщування протягом 20 днів. Потім вимірювали довжину паростків і корінців, визначали масу сухого залишку.

Результати та їх обговорення. Отримані результати представлено в табл. 1-7. У табл. 1 представлено результати зростання корінців і паростків цибулі, їх кількість, довжина, суха маса.

Таблиця 1

Результати ростового тесту на прикладі цибулин цибулі для різних зразків води

\begin{tabular}{|c|c|c|c|c|c|c|c|}
\hline \multirow[b]{2}{*}{$\begin{array}{l}\text { № } \\
\text { 3/п }\end{array}$} & \multirow[b]{2}{*}{$\begin{array}{l}\text { Найменування } \\
\text { зразка води/рН }\end{array}$} & \multicolumn{3}{|c|}{ Зелені паростки } & \multicolumn{3}{|c|}{ Корінці } \\
\hline & & 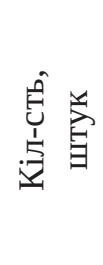 & $\begin{array}{l}\text { 啚 } \\
\text { 是 } \\
\text { 胥 }\end{array}$ & 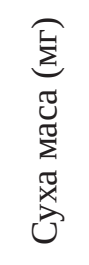 & 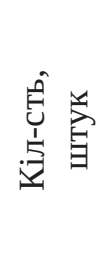 & 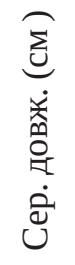 & 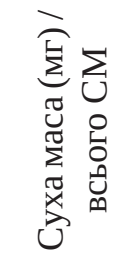 \\
\hline 1.1 & День посадки 27.09.2020 & & & & & & \\
\hline & День замірів 17.10.2020 & & & & & & \\
\hline 1.1 & Мадара оригінал/4,7 & 5 & 9.6 & 300 & 22 & 6.9 & $50 / 350$ \\
\hline 1.2 & Мадара копія на дистил/4,2 & 1 & 0.2 & 20 & 42 & 3.6 & $50 / 70$ \\
\hline 1.3 & Мадара копія на СВД/ 5,2 & 0 & - & - & 21 & 3.4 & $100 / 100$ \\
\hline 2.1 & Вода Приморськ оригінал/ 6,8 & 1 & 1.2 & 50 & - & - & $0 / 50$ \\
\hline 2.2 & $\begin{array}{l}\text { Вода Приморськ } \\
\text { копія на дистил / 3,9 }\end{array}$ & 5 & 6.8 & 200 & 20 & 5.3 & $50 / 250$ \\
\hline 2.3 & $\begin{array}{l}\text { Вода Приморськ } \\
\text { копія на СВД/5,0 }\end{array}$ & 6 & 13.3 & 200 & 2.6 & 6.6 & $100 / 300$ \\
\hline 3.1 & Вода Дренськ. оригінал/ 4,7 & 4 & 7.4 & 200 & 20 & 6.7 & $50 / 250$ \\
\hline 3.2 & $\begin{array}{l}\text { Вода Дренськ. } \\
\text { копія на дистил/5,2 }\end{array}$ & 4 & 7.8 & 100 & 17 & 9.3 & $100 / 200$ \\
\hline 3.3 & $\begin{array}{l}\text { Вода Дренськ. } \\
\text { копія на СВД /5,3 }\end{array}$ & 6 & 9.7 & 200 & 11 & 7.9 & $50 / 250$ \\
\hline 4.1 & $\begin{array}{l}\text { Мінерал. вода } \\
\text { оригінал/4,4 }\end{array}$ & 4 & 5.0 & 100 & 17 & 9.3 & $100 / 200$ \\
\hline 4.2 & $\begin{array}{l}\text { Мінерал вода } \\
\text { копия на дистил/ 4,6 }\end{array}$ & 2 & 2.0 & 50 & 18 & 6.4 & $50 / 100$ \\
\hline 4.3 & $\begin{array}{l}\text { Минерал. вода } \\
\text { копія на СВД/4,9 }\end{array}$ & 6 & 11.1 & 200 & 16 & 4.6 & $50 / 250$ \\
\hline 5.1 & $\begin{array}{l}\text { Вода Св-х. П. і П. } \\
\text { оригінал/4,8 }\end{array}$ & 2 & 1.2 & 50 & 20 & 6.0 & $100 / 150$ \\
\hline 5.2 & $\begin{array}{l}\text { Вода Св-х. П. і П. } \\
\text { копія на дистил/4,6 }\end{array}$ & 3 & 2.2 & 100 & 14 & 4.4 & $100 / 200$ \\
\hline
\end{tabular}


Продовж. табл. 1

\begin{tabular}{|c|c|c|c|c|c|c|c|}
\hline 5.3 & $\begin{array}{l}\text { Вода Св-х. П. і П. } \\
\text { копія на СВД/5,4 }\end{array}$ & 4 & 7.6 & 100 & 35 & 9.1 & $100 / 200$ \\
\hline & $\begin{array}{l}\text { Дата посадки 12.10.2020 } \\
12.10 .2020\end{array}$ & & & & & & \\
\hline & $\begin{array}{l}\text { Дата обрізки 03.11.2020 } \\
\text { 03.11.2020 }\end{array}$ & & & & & & \\
\hline 6 & $\begin{array}{l}\text { Контроль дистил. } \\
\text { вода/7,0 }\end{array}$ & 0 & - & - & 0 & - & - \\
\hline 7 & Контроль вода зі СВД/5,8 & 4 & 1.8 & 80 & 13 & 2.3 & $50 / 130$ \\
\hline 8.1 & $\begin{array}{l}\text { Габрово в/в } \\
\text { оригінал/4,1 }\end{array}$ & 0 & - & - & 14 & 2.5 & $50 / 50$ \\
\hline 8.2 & $\begin{array}{l}\text { Габрово в/в } \\
\text { копія на дистил/4,3 }\end{array}$ & 0 & - & - & 8 & 1.2 & $25 / 25$ \\
\hline 8.3 & $\begin{array}{l}\text { Габрово в/в } \\
\text { копія на СВД/5,1 }\end{array}$ & 1 & 2.5 & 50 & 9 & 2.4 & $50 / 100$ \\
\hline 9.1 & $\begin{array}{l}\text { Варна в/в } \\
\text { оригінал/4,5 }\end{array}$ & 0 & - & - & 12 & 0.8 & $25 / 25$ \\
\hline 9.2 & $\begin{array}{l}\text { Варна в/в } \\
\text { копія на дистил/4,5 }\end{array}$ & 0 & - & - & 0 & - & - \\
\hline 9.3 & $\begin{array}{l}\text { Варна в/в } \\
\text { копія на СВД/5,4 }\end{array}$ & 5 & 5.0 & 250 & 2.6 & 2.0 & $50 / 300$ \\
\hline
\end{tabular}

Аналіз показників кірліанограм зразків води проводили в порівнянні між групами з гарним тестом зростання та слабким для виявлення значущих параметрів для оцінювання біологічної активності води, пов’язаної з її структурою. Оскільки тест зростання проводили на контрольних дистильованої (КД) води та природної води зі свердловини (СВД), отримані результати ЕРМ і ЕРРМ експериментальних зразків оцінювали по відношенню до них (табл. 2).

Таблиця 2

\section{Показники ЕРМ і ЕРРМ відносин експериментальних зразків до контрольних у порівнянні з ТВ4}

\begin{tabular}{|l|c|c|c|c|c|c|}
\hline \multicolumn{7}{|c|}{ Зростання високе } \\
\hline \multicolumn{1}{|c|}{ Зразки/рН } & $\begin{array}{c}\text { ЕРРМ4т } \\
\text { ЕРМ4т }\end{array}$ & $\begin{array}{c}\text { ЕРРМ4/ } \\
\text { ЕРМ4т }\end{array}$ & $\begin{array}{c}\text { ЕРМ4т/ } \\
\text { КД4т }\end{array}$ & $\begin{array}{c}\text { ЕРРМ4/ } \\
\text { КД4т }\end{array}$ & $\begin{array}{c}\text { ЕРМ4т/ } \\
\text { СВД4т }\end{array}$ & $\begin{array}{c}\text { ЕРРМ4/ } \\
\text { СВД4т }\end{array}$ \\
\hline $\begin{array}{l}\text { Приморськ } \\
\text { на дистил./7,0 }\end{array}$ & 4262 & 1,08 & 1,90 & 1,40 & 0,78 & 0,68 \\
\hline Приморськ на СВД/5,0 & 9043 & 1,20 & 1,60 & 1,36 & 0,65 & 0,64 \\
\hline Варна в/в на СВД/5,4 & 6918 & 1,12 & 2,2 & 1,70 & 0,9 & 0,82 \\
\hline Мін.вода оригін./4,4 & 23337 & 1,75 & 1,2 & 1,46 & 0,48 & 0,69 \\
\hline Мін.вода на дистил/4,6 & 18488 & 1,37 & 1,9 & 1,82 & 0,77 & 0,86 \\
\hline Мін.вода на СВД/4,9 & 13015 & 1,37 & 1,35 & 1,29 & 0,55 & 0,61 \\
\hline
\end{tabular}


Продовж. табл. 2

\begin{tabular}{|l|c|c|c|c|c|c|}
\hline Дренськ.оригін/4.7 & 26265 & 1,53 & 1,91 & 2,03 & 0,78 & 0,96 \\
\hline Дренськ. на дистил/5,2 & 10196 & 1,27 & 1,42 & 1,36 & 0,58 & 0,60 \\
\hline Дренськ.на СВД/5.3 & 20192 & 1,38 & 2,04 & 1,96 & 0,83 & 0,93 \\
\hline Мадараоригін/4,7 & 17757 & 1,46 & 1,47 & 1,50 & 0,60 & 0,71 \\
\hline Мадара на СВД/5,0 & 9810 & 1,18 & 2,18 & 1,71 & 0,84 & 0,80 \\
\hline Св. П. і П.оригін/4,8 & 18827 & 1,40 & 1,48 & 1,47 & 0,69 & 0,70 \\
\hline Св. П.і П. на дист./4.60 & 8870 & 1,61 & 1,36 & 1,36 & 0,64 & 0,64 \\
\hline Св. П.і П. на СВД/5.40 & 7190 & 1,90 & 1,52 & 1,52 & 0,71 & 0,72 \\
\hline Габрово в/в на.СВД/4,3 & 10218 & 1,61 & 1,71 & 1,81 & 0,65 & 0,85 \\
\hline М ср & 13625,87 & 1,42 & & 1,58 & & \\
\hline т & 1719,57 & 0,06 & & 0,06 & & \\
\hline
\end{tabular}

Зростання низьке

\begin{tabular}{|l|c|c|c|c|c|c|}
\hline КД/ 3,9 & 11272 & 1,43 & - & - & - & - \\
\hline СВД/5,8 & 14961 & 1,23 & - & - & - & - \\
\hline Приморськ оригін./6,8 & 8867 & 1,20 & 1,46 & 1,26 & 0,60 & 1,26 \\
\hline Варна в/в оригін./4,5 & 11099 & 1,20 & 1,93 & 1,58 & 0,79 & 0,78 \\
\hline Варна в/в дистил/4,5 & 7788 & 1,15 & 1,98 & 1,56 & 0,8 & 0,75 \\
\hline Мадера на дист./4.2 & 3061 & 1,08 & 1,43 & 1,15 & 0,58 & 0,54 \\
\hline Габрово в/в оригін./4,1 & 5527 & 1,13 & 1,00 & 0,80 & 0,41 & 0,37 \\
\hline Габрово на. дистил/4,3 & 9908 & 1,25 & 1,56 & 1,29 & 0,60 & 0,60 \\
\hline М ср & 9060,38 & 1,21 & - & 1,27 & - & - \\
\hline m & 1300,53 & 0,04 & - & 0,12 & - & - \\
\hline t-критерій Стьюдента & 2,12 & 2,91 & 0,71 & 2,11 & 0,78 & 0,23 \\
\hline р & $<0,05$ & $<0,05$ & $>0,05$ & $<0,05$ & $>0,05$ & $>0,05$ \\
\hline
\end{tabular}

Порівнюючи величин ЕРМ і ЕРРМ із ТВ4 за відношенню до КД, виявили статистично значимий для прогнозування біологічної активності води показник ЕРРМ.

Вірогідність відмінностей між показниками груп при порівнянні величин ЕРМ і ЕРРМ із ТВ3 не виявили. Це $є$ закономірним для початкових природних вод, оскільки ТВ3 - вода також із природних джерел. Наступне підкреслює, що підготовлені інформаційні копії із них на дистиляті з гарним зростанням мають ті ж закономірності. Це демонструє реальне енергоінформаційне перенесення з оригінальним зразком на дистильовану воду та на воду зі свердловини, з їх квантовими перебудовами.

Для більшої стандартизації і деталізації аналізу властивостей води, залежно від тесту зростання, проаналізовано показники відношень отриманих первинних величин за ТВ1, ТВ3 і ТВ4 в експериментальних зразках до таких у КД (табл. 3). 


\section{Аналіз Кі-світіння у зразків експериментальних вод за результатами} порівняння ЕРМ гістограми яскравості з типовими водами

\begin{tabular}{|c|c|c|c|c|c|c|c|c|}
\hline \multicolumn{9}{|c|}{ Зростання високе } \\
\hline Зразки/рН & $\begin{array}{c}\text { ЕРM1/ } \\
\text { КД1 }\end{array}$ & $\begin{array}{c}\text { ЕРМЗ/ } \\
\text { КДЗ }\end{array}$ & $\begin{array}{c}\text { ЕРM4/ } \\
\text { КД4 }\end{array}$ & $1 / 2$ & $1 / 3$ & $2 / 3$ & $3 / 2$ & $\begin{array}{c}\text { EPM } \\
\text { TB3/ } \\
\text { TB4 }\end{array}$ \\
\hline Прим. на дистил/3,9 & 1,90 & 1,81 & 1,91 & 1,05 & 0,99 & 0,95 & 1,10 & 1,26 \\
\hline Прим. на СВД/5,0 & 2,00 & 1,40 & 1,60 & 1,43 & 1,25 & 0,87 & 1,14 & 1,16 \\
\hline Варна в/в наСВД/5,4 & 2,61 & 2,06 & 2,22 & 1,3 & 1,27 & 0,93 & 1,08 & 1,23 \\
\hline Мін.вода оригін./4,4 & 1,52 & 1,24 & 1,20 & 1,25 & 1,27 & 1,03 & 1,00 & 1,38 \\
\hline $\begin{array}{l}\text { Мін.вода } \\
\text { на дист./4,6 }\end{array}$ & 2,12 & 1,80 & 1,89 & 1,17 & 1,12 & 0,95 & 1,05 & 1,26 \\
\hline $\begin{array}{l}\text { Мін.вода } \\
\text { на СВД/4,9 }\end{array}$ & 1,53 & 1,13 & 1,35 & 1,36 & 1,13 & 0,84 & 1,19 & 1,11 \\
\hline $\begin{array}{l}\text { Дренськ. } \\
\text { оригін/4.7 }\end{array}$ & 2,12 & 1,43 & 1,91 & 1,50 & 1,11 & 0,75 & 1,33 & 1,0 \\
\hline Дренськ. на дист/5,16 & 1,62 & 1,03 & 1,42 & 1,60 & 1,14 & 0,72 & 1,38 & 0,96 \\
\hline Дренськ. на СВД/5.3 & 2,34 & 1,62 & 2,04 & 1,44 & 1,15 & 0,79 & 1,26 & 1,05 \\
\hline Мадара оригін/4,7 & 1,71 & 1,16 & 1,47 & 1,42 & 1,16 & 0,79 & 1,27 & 1,05 \\
\hline Мадара на СВД/5,0 & 2,11 & 1,45 & 2,05 & 1,46 & 1,03 & 0,71 & 1,41 & 0,93 \\
\hline Св.П. і П. оригін/4,8 & 1,62 & 1,07 & 1,39 & 1,45 & 1,17 & 0,77 & 1,30 & 1,02 \\
\hline Св.П.і П. на дист./4.60 & 1,81 & 1,29 & 1,69 & 1,38 & 1,07 & 0,80 & 1,31 & 1,07 \\
\hline Св.П.і П. на СВД/5.40 & 2,24 & 1,84 & 1,90 & 1,22 & 1,18 & 0,97 & 1,03 & 1,29 \\
\hline Габрово в/в на СВД/4,3 & 1,72 & 1,57 & 1,61 & 1,08 & 1,07 & 0,98 & 1,03 & 1,30 \\
\hline \multicolumn{9}{|c|}{ Зростання низьке } \\
\hline КД/7,0 & - & - & - & - & & - & & 1,33 \\
\hline СВД/5,8 & 2,70 & 2,10 & 2,46 & 1,28 & 1,10 & 0,85 & 1,17 & 1,17 \\
\hline Приморськ оригін./6,8 & 1,70 & 1,38 & 1,46 & 1,34 & 1,16 & 0,94 & 1,06 & 1,25 \\
\hline Варна в/в оригін./4,5 & 1,60 & 1,87 & 1,93 & 0,84 & 0,85 & 0,97 & 1,03 & 1,29 \\
\hline Варна в/в на дистил./4,5 & 2,20 & 1,75 & 1,98 & 1,26 & 1,11 & 0,88 & 1,13 & 1,17 \\
\hline Мадара на дистил./4,2 & 1,60 & 1,24 & 1,44 & 1,33 & 1,11 & 0,86 & 1,16 & 1,15 \\
\hline Габрово в/в оригін./4,1 & 1,20 & 1,0 & 1,01 & 1,20 & 1,19 & 1,0 & 1,01 & 1,34 \\
\hline Габрово в/в дистил /4,3 & 1,52 & 1,26 & 1,46 & 1,21 & 1,04 & 0,86 & 1,16 & 1,15 \\
\hline $\begin{array}{l}\mathrm{t}, \\
\mathrm{p}\end{array}$ & 0,67 & 0,31 & 0,96 & 1,60 & 0,99 & 1,46 & $\begin{array}{c}2,11 \\
<0,05\end{array}$ & $\begin{array}{c}2,02 \\
<0,05\end{array}$ \\
\hline
\end{tabular}




\section{Аналіз Кі-світіння у зразків експериментальних вод за результатами порівняння ЕРРМ гістограми яскравості з типовими водами}

\begin{tabular}{|c|c|c|c|c|c|c|c|c|}
\hline \multicolumn{9}{|c|}{ Зростання високе } \\
\hline Зразки & $\begin{array}{c}\text { ЕРРМ1т } \\
/ \text { ҚД1т }\end{array}$ & $\begin{array}{c}\text { ЕРРМЗт } \\
\text { /КДЗт }\end{array}$ & $\begin{array}{c}\text { ЕРРМ4т } \\
/ \text { КД4т }\end{array}$ & $1 / 2$ & $1 / 3$ & $2 / 3$ & $3 / 2$ & $\begin{array}{l}\text { TB3т } \\
/ \text { TB4T }\end{array}$ \\
\hline Приморськ на дистил/ 3,9 & 1,60 & 1,48 & 1,45 & 1,08 & 1,10 & 1,00 & 0,98 & 1,20 \\
\hline Приморськ на СВД/5,0 & 1,37 & 1,22 & 1,35 & 1,12 & 1,00 & 0,90 & 1,11 & 1,11 \\
\hline Варна в/в на СВД/5,4 & 1,89 & 1,72 & 1,73 & 1,10 & 1,09 & 1,00 & 1,00 & 1,23 \\
\hline Мін.вода оригін./4,4 & 1,04 & 1,01 & 1,46 & 1,03 & 0,71 & 0,68 & 1,45 & 1,35 \\
\hline Мін.вода на дист./4,6 & 1,96 & 1,76 & 1,82 & 1,11 & 1,08 & 0,97 & 1,03 & 1,21 \\
\hline Мін.вода на СВД/4,9 & 0,96 & 0,78 & 1,30 & 1,23 & 0,74 & 0,60 & 1,67 & 0,95 \\
\hline Дренськ. оригін/4,7 & 1,98 & 1,52 & 2,03 & 1,30 & 0,97 & 0,75 & 1,34 & 0,92 \\
\hline Дренськ. на дистил/5,2 & 1,11 & 0,75 & 1,26 & 1,48 & 0,88 & 0,60 & 1,68 & 0,73 \\
\hline Дренськ. на СВД/5,3 & 1,93 & 0,99 & 1,96 & 1,95 & 0,98 & 0,77 & 1,98 & 0,96 \\
\hline Мадара оригін/4,7 & 1,44 & 1,30 & 1,50 & 1,30 & 0,96 & 0,74 & 1,35 & 0,92 \\
\hline Мадара на СВД/5,0 & 1,98 & 1,45 & 1,70 & 1,36 & 1,16 & 0,85 & 1,17 & 1,08 \\
\hline Св. П. і П. оригін./4,8 & 1,41 & 1,06 & 1,50 & 1,33 & 0,94 & 0,71 & 1,42 & 0,90 \\
\hline Св. П.і П. дистил/4,6 & 1,25 & 0,95 & 1,40 & 1,32 & 0,89 & 0,68 & 1,47 & 0,87 \\
\hline Св.П.і П. на СВД/5,4 & 1,69 & 1,57 & 1,50 & 1,08 & 1,13 & 1,05 & 0,96 & 1,28 \\
\hline Габрово на СВД/4,3 & 1,69 & 1,57 & 1,80 & 1,08 & 0,94 & 0,87 & 1,15 & 1,69 \\
\hline Сер. арифм (M) & - & - & - & 1,26 & - & 0,81 & 1,32 & - \\
\hline Похибка сер. (m) & - & - & - & 0,06 & - & 0,04 & 0,08 & - \\
\hline \multicolumn{9}{|c|}{ Зростання низьке } \\
\hline КД/7,0 & - & - & - & - & - & - & - & 1,24 \\
\hline СВД/5,8 & 2,11 & 1,95 & 2,11 & 1,08 & 0,90 & 0,90 & 1,08 & 1,14 \\
\hline Приморськ оригін./6,8 & 1,35 & 1,26 & 1,26 & 1,07 & 1,00 & 1,00 & 1,00 & 1,24 \\
\hline Варна в/в оригін./4,5 & 2,10 & 1,90 & 1,80 & 1,11 & 1,05 & 1,05 & 0,95 & 1,20 \\
\hline Варна в/в дистил/4,5 & 1,67 & 1,48 & 1,62 & 1,13 & 1,08 & 1,08 & 1,08 & 1,15 \\
\hline Мадара на дистил./4,2 & 1,08 & 0,86 & 1,15 & 1,23 & 0,74 & 0,74 & 1,34 & 0,93 \\
\hline Габрово в/в оригін./4,1 & 0,83 & 0,78 & 0,80 & 1,06 & 0,97 & 0,97 & 1,02 & 1,20 \\
\hline Габрово в/в дистил /4,3 & 1,52 & 1,26 & 1,29 & 1,21 & 1,18 & 0,98 & 1,02 & 1,11 \\
\hline Сер. арифм (M) & - & - & - & 1,13 & - & 0,96 & 1,07 & - \\
\hline Похибка сер. (m) & - & - & - & 0,02 & - & 0,04 & 0,05 & - \\
\hline $\begin{array}{l}\mathrm{t}, \\
\mathrm{p}\end{array}$ & 0,95 & 0,41 & 0,82 & $\begin{array}{c}2,11 \\
<0,05\end{array}$ & 0,18 & $\begin{array}{c}2,49 \\
<0,05\end{array}$ & $\begin{array}{c}2,71 \\
<0,05\end{array}$ & 0,8 \\
\hline
\end{tabular}


Відносини отриманих величин використовували, як умовні коефіцієнти, для оцінювання переважного виду та ступеня когерентності експериментальних зразків води з раніше виявленим критеріям різниць величин ЕРМ і ЕРРМ із ТВ, приготованої в експерименті КГ води на дистиляті [9]. Значення показників коефіцієнтів: 4 - відображає відмінність експериментальної води від ТВ3 - природного порівняння з КД; 5 - відображає відмінність експериментальної води від ТВ4 - природної монастирської у порівнянні з КД; 6, 7 - відображають відмінність експериментальної води від ТВ3 і TB4 між собою в порівнянні з КД.
Використовуючи коефіцієнти, виявили додатково по два статистично значущих показника величин гістограм ЯКС експериментальних зразків води, що мають вплив на тест зростання за відмінності їх ЕРМ і ЕРРМ від природної води та з територій монастирів.

Раніше нами встановлено критерії виду та ступеня когерентної води, експериментально приготованої на дистиляті за величинам ЕРМ і ЕРРМ гістограм ЯКС на рентгенівській плівці (табл. 5) [10].

Критерії когерентної води, приготованої на дистильованій воді

\begin{tabular}{|c|c|c|c|c|c|c|c|}
\hline \multicolumn{8}{|c|}{ За величиною ЕРМ } \\
\hline Критерії по КГД & Коефіцієнти & $+1 \mathrm{ct}$ & $+2 \mathrm{cT}$ & $+3 \mathrm{ct}$ & $-1 \mathrm{ct}$ & $-2 \mathrm{ct}$ & $-3 c t$ \\
\hline $\begin{array}{l}\text { Відміна величин } \\
\text { від ТВ }\end{array}$ & - & 5 п-в & 5 п-в & 5 п-в & 4 п-а & 4 п-а & 4 п-а \\
\hline $\begin{array}{l}\text { TB2 i TB3 } \\
<\text { TB1 i TB4 }\end{array}$ & K $5<$ K 4 i 7 & + & - & - & + & - & + \\
\hline TB3 $<$ TB4 & $\begin{array}{c}\mathrm{T} 3 / \mathrm{T} 4<1 \\
(\text { (брали<0,85) }\end{array}$ & + & - & - & + & - & + \\
\hline $\begin{array}{l}\text { TВ2 і ТВ3, ТВ1 } \\
\text { іТВ4 - близькі } \\
\text { між собою }\end{array}$ & K $5<$ K 4 i 7 & + & - & - & - & - & - \\
\hline $\begin{array}{l}\text { Величини всіх } \\
\text { ТВ - близькі } \\
\text { між собою }\end{array}$ & $\begin{array}{l}\text { Величини } \\
\text { всіх коеф-ів } \\
\text { близькі до } 1\end{array}$ & - & $\begin{array}{c}1-4-x \\
\text { TB }\end{array}$ & $\begin{array}{c}1-4-\mathrm{X} \\
\text { TB }\end{array}$ & - & $\begin{array}{c}1-3-x \\
\text { TB }\end{array}$ & - \\
\hline \multicolumn{8}{|c|}{ За величиною ЕРРМ } \\
\hline Критерії по КГД & $\begin{array}{c}\text { Відповідності } \\
\text { відносин }\end{array}$ & $+1 \mathrm{cT}$ & $+2 \mathrm{ct}$ & $+3 \mathrm{cT}$ & $-1 \mathrm{ct}$ & $-2 \mathrm{ct}$ & $-3 c \mathrm{~T}$ \\
\hline $\begin{array}{l}\text { Відмінності } \\
\text { величин від ТВ }\end{array}$ & - & 5 п-в & 5 п-в & 5 п-в & 4 п-а & 4 п-а & 4 п-а \\
\hline $\begin{array}{l}\text { ТВ2 і ТВ3 < } \\
\text { TВ1 і ТВ4; ТВ1 } \\
\text { і ТВ4 близькі }\end{array}$ & K $5<$ K 4 i 7 & + & - & - & - & - & - \\
\hline $\begin{array}{l}\text { ТВ2 < ТВ1; } \\
\text { ТВ2 < ТВ4 в } \\
\text { однаковій мірі }\end{array}$ & $\begin{array}{c}\text { К } 6 \text { і } 7 \\
\text { близькі до } 1\end{array}$ & + & - & - & - & - & - \\
\hline $\begin{array}{l}\text { Різниці ТВ2 і } \\
\text { ТВ3, ТВ1 і ТВ4 } \\
\text { - близькі між собою }\end{array}$ & K $5<$ K 4 i 7 & + & - & - & - & - & - \\
\hline
\end{tabular}


Продовж. табл. 5

\begin{tabular}{|l|c|c|c|c|c|c|c|}
\hline $\begin{array}{l}\text { Величини всіх } \\
\text { ТВ - близькі } \\
\text { між собою }\end{array}$ & $\begin{array}{c}\text { Величини } \\
\text { всіх коеф-ів } \\
\text { близькі до } 1\end{array}$ & - & + & - & - & + & - \\
\hline ТВ3 $<$ ТВ1,2,4 & $\begin{array}{l}\text { Т3/Т4 }<1, \\
\text { К4 і К7 }>1\end{array}$ & - & - & + & - & - & - \\
\hline ТВ4 > ТВ1-3 & $\begin{array}{l}\text { Т4/Т3 }>1, \\
\text { К4 і К7 }>1\end{array}$ & - & - & + & - & - & + \\
\hline ТВ3 > ТВ1-3 & $\begin{array}{l}\text { Т3/Т4 }<1, \\
\text { К4 і К7 }<1\end{array}$ & - & - & - & + & + & - \\
\hline
\end{tabular}

Примітка: $\mathrm{K}$ - коефіцієнт

Далі порівняли показники гістограм експериментальних зразків води з критеріями виду та ступеня когерентної води (табл. 6).

Таблиця 6

\section{Когерентність експериментальних зразків води}

\begin{tabular}{|c|c|c|c|c|c|c|c|c|c|c|c|c|c|}
\hline \multicolumn{14}{|c|}{ Зростання велике } \\
\hline Зразки/рН & $\begin{array}{c}\text { Ознаки } \\
\text { КГ води }\end{array}$ & 1 & 2 & 3 & 4 & 5 & 6 & 7 & 8 & 9 & 10 & 11 & 12 \\
\hline $\begin{array}{l}\text { Приморськ } \\
\text { на дист./3,9 }\end{array}$ & $(+2,-3)$ & 5 & - & - & + & 5 & - & - & + & - & + & - & - \\
\hline $\begin{array}{l}\text { Приморськ. } \\
\text { на СВД/5,0 }\end{array}$ & $(+1,-2)$ & 5 & + & + & - & 5 & - & - & + & - & - & - & - \\
\hline $\begin{array}{l}\text { Варна в/в } \\
\text { на СВД/5,4 }\end{array}$ & $(+2)$ & 5 & - & - & - & 5 & - & - & + & - & + & - & - \\
\hline $\begin{array}{l}\text { Мін.вода } \\
\text { оригін./4,4 }\end{array}$ & $(+2,+3,-2)$ & 5 & - & + & - & 5 & + & + & - & $\mathrm{K}>1$ & + & + & - \\
\hline $\begin{array}{l}\text { Мін.вода } \\
\text { на дист/4,6 }\end{array}$ & $(+2,+3,-2)$ & 5 & - & - & + & 5 & - & - & + & - & + & + & - \\
\hline $\begin{array}{l}\text { Мін. вода } \\
\text { на СВД/4,9 }\end{array}$ & $(+1,-2)$ & 5 & + & + & - & 5 & + & + & - & + & - & + & сум \\
\hline $\begin{array}{l}\text { Дренськ } \\
\text { оригін/4,7 }\end{array}$ & $(+1,+3,-2)$ & 5 & + & + & - & 5 & + & + & - & + & - & + & сум \\
\hline $\begin{array}{l}\text { Дренськ } \\
\text { на дистил/5,2 }\end{array}$ & $(+1,+3,-2)$ & 5 & + & + & - & 5 & + & + & - & + & - & + & + \\
\hline $\begin{array}{l}\text { Дренськ } \\
\text { на СВД/5.3 }\end{array}$ & $(+1,+3,-2)$ & 5 & + & + & - & 5 & + & + & - & + & - & + & сум \\
\hline $\begin{array}{l}\text { Мадера } \\
\text { оригін/4,7 }\end{array}$ & $(+1,+3,-2)$ & 5 & + & + & - & 5 & + & + & - & + & - & + & сум \\
\hline $\begin{array}{l}\text { Мадера } \\
\text { на СВД/5,0 }\end{array}$ & $(+1,+2,-2)$ & 5 & + & + & - & 5 & + & - & - & + & - & + & - \\
\hline
\end{tabular}


Продовж. табл. 6

\begin{tabular}{|c|c|c|c|c|c|c|c|c|c|c|c|c|c|}
\hline $\begin{array}{l}\text { Св. П. і П. } \\
\text { оригін/4,8 }\end{array}$ & $(+1,+3,-2)$ & 5 & + & + & - & 5 & + & + & - & + & - & + & сум \\
\hline $\begin{array}{l}\text { Св. П.і П. } \\
\text { на дист./4,6 }\end{array}$ & $(+1,+3,-2)$ & 5 & + & + & - & 5 & + & + & - & + & - & + & + \\
\hline $\begin{array}{l}\text { Св. П.і П. на } \\
\text { СВД/5,4 }\end{array}$ & $(+2)$ & 5 & + & K5> K7 & $4=5$ & 5 & - & - & + & - & + & - & - \\
\hline $\begin{array}{l}\text { Габрово в/в. } \\
\text { на СВД/4,3 }\end{array}$ & $(+2,-2)$ & 5 & - & - & + & 5 & - & - & + & - & + & + & - \\
\hline \multicolumn{14}{|c|}{ Зростання низьке } \\
\hline СВД/5,8 & $(+1,+2)$ & 5 & + & - & сум & + & + & - & - & - & сум & - & - \\
\hline $\begin{array}{l}\text { Приморськ } \\
\text { оригін./6,8 }\end{array}$ & $(+1,+2)$ & 5 & + & сум & - & + & + & - & - & - & + & - & - \\
\hline $\begin{array}{l}\text { Варна в/в } \\
\text { оригін./4,5 }\end{array}$ & $(+1,+2)$ & 5 & - & + & сум & + & + & - & - & - & + & - & - \\
\hline $\begin{array}{l}\text { Варна в/в } \\
\text { на дист/4,5 }\end{array}$ & $(+1,+2)$ & 5 & + & - & сум & сум & + & - & - & - & сум & - & - \\
\hline $\begin{array}{l}\text { Мадара } \\
\text { на дис- } \\
\text { тил./4,2 }\end{array}$ & $(+1,+2,-2)$ & 5 & + & - & сум & сум & + & + & - & - & - & + & + \\
\hline $\begin{array}{l}\text { Габрово } \\
\text { оригін./4,1 }\end{array}$ & $(+1,+2)$ & 5 & - & + & сум & + & + & - & - & - & + & - & - \\
\hline $\begin{array}{l}\text { Габрово на } \\
\text { дистил /4,3 }\end{array}$ & $(+1,+2)$ & 5 & + & сум & сум & сум & + & - & $\mathrm{K}>\mathrm{K} 7$ & - & сум & - & - \\
\hline
\end{tabular}

Примітка: (+) — ознака присутня, (-) — ознака відсутня: КГ — когерентність, К — коефіцієнт; 1 - ЕРМ порядок величини; 2 — ЕРM К5 <К4; 3 — ЕРМ К5 <К7; 4- ЕРМ К4 = К5 = К7; 5 — ЕРРМ порядок величини; 6 - ЕРРМ К5

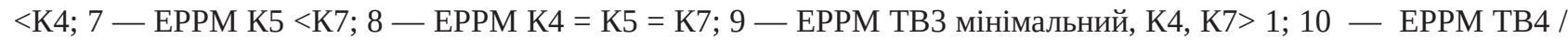
ТВ3> 1; 11 - ЕРРМ ТВ3 максимальний, Т3 / Т4 <1, К4 і K7> 1; 12 — ЕРРМ ТВ4 максимальний, Т4 / Т3> 1, К4 і K7> 1; (+) — правообертальна КГВ, (-) — лівообертальна КГВ; 1, 2, 3 - ступеня когерентності. При зіставленні показників оцінювали їх, як відрізняються між собою, при різниці їх величин більше 1,15 і менше 0,85; в іншому випадку відмінності сумнівні — сум.

При аналізі виду та ступеня когерентності експериментальних вод із високим тестом зростання звертає увагу наявність у більшості з них ознак різної когеренізації води, на відміну від зразків із низьким тестом зростання. Ознаки (-) типу когерентної води були у більшості зразків (73\%) із хорошим зростанням і тільки в 1-ого зразка (14 \%) із низьким зростанням. Відповідно до літературних даних, саме природна вода має змішаний тип когерентності, що обумовлює стійкість ії властивостей. А саме лівообертальний тип КГ води має більш виражену біологічну дію [11].

У той же час, для більшої верифікації стану когерентності водних об’єктів доцільно подальше вивчення цього питання в порівнянні виявлених критеріїв когерентності на дистиляті з такими на природній питній воді. Можливо, буде виявлена значимість в оцінюванні КГ води та коефіцієнта К6 (відношення величини ЕРРМЗт / КДЗт до величини ЕРРМ4т / КД4т), що не притаманний КГД - у минулих дослідженнях, але в наведеному аналізі експериментальних вод, із урахуванням тесту зростання, мав статистично достовірні відмінності.

Вода може бути високо когерентною, але зі слабким тестом зростання через хімічний склад, не сумісного з біологічним життям (вода зі Св. джерела Приморська - надлишок нітратів, зі свердловини - заліза). I навпаки, з задовільним 
хімічним складом за існуючим ДСТУ, але зі слабо упорядкованою структурою. При задовільному хімічному складі, але низькою когерентністю, біологічне зростання також буде недостатнім за наявного потенціалу через низьку відповідь води на зовнішнє енергетичне джерело квантового збудження. Останній $є$ причиною всіх електричних явищ і фотонної емісії у клітинах. Ультрафіолетова частина спектра електромагнітної складової відома, як митогенетичне біополе, що індукує митотичну клітинну активність [12].

Отже, тест зростання продемонстрував наступні можливі варіанти фізико-хімічного стану води (табл. 7).

Таблиця 7

Варіанти поєднань хімічного складу та когерентності експериментальної води за результатами тесту зростання

\begin{tabular}{|c|c|c|c|c|c|}
\hline Варіанти & КГ-сть води & $\begin{array}{c}\text { Нормальний } \\
\text { хім. склад }\end{array}$ & $\begin{array}{c}\text { Зростання } \\
\text { на ІК на дистил. }\end{array}$ & $\begin{array}{c}\text { 3ростання } \\
\text { на ІК на СВД }\end{array}$ & $\begin{array}{c}\text { Зростання } \\
\text { на оригіналі }\end{array}$ \\
\hline $\begin{array}{c}\text { (1)- Св. джерело } \\
\text { Приморськ }\end{array}$ & +++ & - & + & + & + \\
\hline $\begin{array}{c}\text { (2) - мон. Дренський, } \\
\text { Св-х П. і П., мінер. вода }\end{array}$ & ++ & ++ & + & + \\
\hline $\begin{array}{c}\text { (3) - Мадара } \\
\text { (4) - Варна в/в, Габрово в/в }\end{array}$ & + & + & - & + \\
\hline
\end{tabular}

Отримані дані можна порівняти з результатами оцінювання виду та ступеня когерентності зразків. Зокрема, при першому варіанті у зразка IK води із Св. джерела (Приморськ), високо когерентної за біологічною активністю, поряд з (+) типом когерентності, були ознаки $(-2,-3)$ КГ, на відміну від усіх інших зразків. Лівобічна поляризація за експериментальними даними має більшу біологічну активність, ніж правобічна (+) $[1,11]$.

У зразків води другого варіанту переважали ознаки $(+3,-2)$ когерентності. У зразків третього варіанту, як оригіналу, так і IK на дистиляті та на воді зі свердловини, були ознаки (+2). Проте, зростання IK на дистиляті було низьким. Можливо, це пов'язано 3 досить кислим середовищем води (рН 4,2), тоді як у перших - pН були ближче до 5,0. У зразків четвертого варіанту, крім одного, не було ознак (-) КГ і 3-го ступеня (+) КГ.

Практичний вихід. При незадовільному біологічному зростанні об'єкта необхідно визначити провідну причину — незадовільний хімічний склад або низька когерентність води з метою адекватної їх корекції.

При варіанті 1: якщо хімічний склад води незадовільний, а поліпшити його немає технічної можливості, при високій її КГ досить приготувати ІКс цієї води, як на дистиляту, так і на будь-яку природну воду.

При варіанті 3: якщо хімічний склад води задовільний, можна посилити ії біологічне зростання, підвищивши ї̈ когерентність приготуванням IK на ній із води з високою КГ-ма (що змінює дистиляту).

При варіанті 4: якщо немає зростання на IK води на дистиляті, але $є$ на IK води на природній, що перевищує норму вмістом хімічних речовин, то ця вода має достатню для біологічної активності когерентність, але недостатньо задовільний хімічний стан. У такому випадку необхідна корекція останнього. 
Ступінь когерентності води попередньо перевіряють за біологічною активністю ї̈ IK на дистиляті. Найбільш високогерентна вода надає їй біологічну активність при енергоінформаційному перенесенні.

Однак, при порівнянні такої води (Приморськ, Св. джерело) 3 виявленими раніше критеріями когерентності (приготовленої КГ води на дистиляті), когерентність їі була не найвища серед інших зразків. Показники ЕРМ і ЕРРМ $є$ інтегральними, що не відображають стан зміни властивостей води по її областям, із різною пов’язаністю або когерентністю доменів. Потрібен більш детальний аналіз яркісної оцінки піддіапазонів гістограм, що буде проведено в подальшому. У минулих наших дослідженнях при порівнянні результатів кірліанограм і фізичних вимірів зразків води зі Св. джерел Києво-Печерської Лаври виявлено не повну їхню відповідність, оскільки наявні стандартні фізичні методи не фіксують тонкоматеріальні хвильові процеси, що відбуваються, квантові переходи в воді [13].

\section{Література.}

1. Краснобрыжев В. Г. Глобальный технологический ресурс макроскопической нелокальности. Когерентные технологии. Комплементарная когерентная вода : монография / Краснобрыжев В. Г. - Кишинев: LAP LAMBERT Academic publishing, 2012. - 120 с.

2. Способ получения фотографических снимков различного рода объектов / Кирлиан С. Д. : Авт. свид. №106401, кл. G03B 41/00. Подано 05.09.1949; опубл. 01.01.1957 г.

3. Метод Кирлиан / Колтовой Н.А. - 2020. - Режим доступа: https://koltovoi.nethouse.ru.

4. Спосіб оцінки енергоінформаційного стану рідинно фазного об'єкту і пристрій для його здійснення /Пісоцька Л. А., Лапицький В. М., Боцман К. І., Геращенко С. В. : пат. України на корисну модель. № 22212, заявл. 17.04.06; опубл. 05.04.07. Бюл. № 5.

5. Устройство для регистрации изображения Кирлиана-свечения биологических объектов / Песоцкая Л. А., Минцер О. П., Глухова Н. В. : пат. Украины на полезную модель. № 100879, от 10.08.2015. Бюл. № 15.

6. Глухова Н. В. Метод расчета неопределенности измерений геометрических параметров газоразрядных изображений / Глухова Н. В. // Системи обробки інформації. - 2016. - № 6 (143). - С. 32-35.

7. Использование метода газоразрядного свечения для оценки оздоровительных свойств воды / Л. Песоцкая, Г. Ковальчук, Н. Глухова и др. //
У статті Нобелівського лауреата Люка Монанье [1] описано ефекти пам'яті води по відношенню до ДНК при взаємодії зі слабким електромагнітним полем. Ці ефекти пояснюються Монанье як феномени резонансу наноструктур ДНК і води. Можливо при приготуванні IK із високо когерентної води зі Св. джерела спостерігаються такі ж ефекти з ДНК живих істот, що присутні в ній.

Висновки. 1. Метод кірліанфотографії крапель води на рентгенівській плівці досить інформативний для оцінювання природних властивостей води з аналізу іiї електрофотонної емісії та може використовуватись як експрес-метод.

2. Оцінювання передбачуваної біологічної активності води повинна включати поряд із ДСТУ хімічного складу, аналіз її когерентного стану, що дає можливість оптимізації її біологічної активності.

3. Перспективним являється подальше розроблення способу автоматизованого аналізу кірліанограм води та рідкофазних об'єктів для прикладного використання.

Международный журнал «Устойчивое развитие». - 2020. - № 2. - С. 10-19.

8. Прибор для энергоинформационного переноса лекарственных свойств препаратов, приготовляемых по гомеопатическому принципу / Михайлов В. А., Пархоменко Ю. А. : пат. РФ на полезную модель. № 4224 U1, заяв. 22.04.96; опубл. 16.06.97, Бюл. № 20.

9. Способ и оборудование для модификации топлива. Sposób i urządzenie do modyfikacji paliwa / Краснобрыжев В. Г. : пат. Польши на полезную модель № 207357, заяв. 05.09.2006, опубл. 05.03.2007.

10. Способ определения степени когерентности состояния воды / Песоцкая Л. А., Минцер О. П., Глухова Н. В. - Пат. Украины на изобретение. №112809, заяв. 02.03.2015; опубл. 25.10.2016. - Бюл. № 20. - 8 с.

11. Свойства когерентной воды / Краснобрыжев В. Г., Курик М. В. // Квантовая Магия. - 2010. - Т. 7, Вып. 2. - С. 2161-2166.

12. Гурвич А. Г. Принципы аналитической биологии и теории клеточных полей / Гурвич А. Г. - М.: Наука, 1991. - 250 с.

13. Кирлинография энерго-информационных взаимодействий воды : монография / Курик М. В., Песоцкая Л. А., Глухова Н. В., Евдокименко Н. М. Днепропетровск : Литограф, 2015. - 138 с. 


\section{Reference.}

1. Krasnobryzhev, V. (2012). A global technological resource for macroscopic disloyalty. Coherent technology. Complementary coherent water. Kishiney: LAP LAMBERT Academic publishing. [In Russian].

2. Kirlian, S. D. (1949). Sposob polucheniya fotograficheskih snimkov razlichnogo roda obektov [The method of obtaining photographic images of various kinds of objects]. Avt. svid. (Certificate of authorship). [In Russian].

3. Koltovoi, H. A. (2020). Metod Kirlian [Kirlian method]. URL: https://koltovoi.nethouse.ru.

4. Pisocka, L. A., Lapytskyi, V. M., Botsman, K. I., Herashchenko, S. V. (2007). Sposib otsinki energoinformatsiynogo stanu ridinno faznogo ob’ektu i pristriy dlya yogo zdiysnennya [Method of assessing the energy-informational mill of a single-phase facility and an attachment for a healthy state of affairs]. Patent Ukrainy na izobretenie № 22212; opubl. 05.04.07, 5. [In Ukrainian].

5. Pisocka, L. A., Mintser, O. P., Gluhova, N. V. (2015). Ustroystvo dlya registratsii izobrazheniya Kirlianasvecheniya biologicheskih ob'ektov [A device for registering an image of the Kirlian glow of biological objects]. Patent Ukrainy na izobretenie № 100879; from 10.08.2015, 15. [In Ukrainian].

6. Gluhova, N. V. (2016). Metod rascheta neopredelennosti izmereniy geometricheskih parametrov gazorazryadnyih izobrazheniy [Method for calculating the measurement uncertainty of the geometric parameters of gasdischarge images]. Sistemi obrobki informatsiyi (Information processing systems), 6 (143), 32-35. [In Ukrainian].

7. Pisocka, L., Kovalchuk, G., Gluhova, N. et al. (2020). Ispolzovanie metoda gazorazryadnogo svecheniya dlya otsenki ozdorovitelnyih svoystv vodyi [Using the gas-discharge glow method to assess the healthimproving properties of water]. Mezhdunarodnyiy zhurnal «Ustoychivoe razvitie» (International Journal of Sustainable Development), 2, 10-19. [In Russian].
8. Mykhailov, V. A., Parkhomenko, Yu. A. (1997). Pribor dlya energoinformatsionnogo perenosa lekarstvennyih svoystv preparatov, prigotovlyaemyih po gomeopaticheskomu printsipu [Device for energyinformational transfer of medicinal properties of drugs prepared according to the homeopathic principle]. Patent of Russian Federation for a useful model № 4224 U1; opubl. 16.06.97, 20. [In Russian].

9. Krasnobryzhev, V. G. (2007). Sposob i oborudovanie dlya modifikatsii topliva [Method and equipment for fuel modification]. Patent of Polish for a useful model № 207357; opubl. 05.03.2007. [In Russian].

10. Pisocka, L. A., Mintser, O. P., Gluhova, N. V. (2016). Sposob opredeleniya stepeni kogerentnosti sostoyaniya vody [The method of determining the degree of coherence of the state of water]. Patent Ukrainy na izobretenie № 112809; opubl. 25.10.2016, 20. [In Ukrainian].

11. Krasnobryzhev, V. G., Kuryk, M. V. (2010). Svoystva kogerentnoy vodyi [Properties of coherent water]. Kvantovaya Magiya (Quantum Magic), 7, 2, 21612166. [In Russian].

12. Gurvich, A. G. (1991). Printsipyi analiticheskoy biologii i teorii kletochnyih poley [Principles of analytical biology and cell field theory]. Moscow, Nauka. [In Russian].

13. Kuryk, M. V., Pisocka, L. A., Gluhova, N. V., Evdokymenko, N. M. (2015). Kirlinografiya energoinformatsionnyih vzaimodeystviy vodyi [Kirlinography of energy-informational interactions of water]. Dnepropetrovsk, Litograf. [In Ukrainian]. 